\title{
Mitigating Climate Change in Nigeria: African Traditional Religious Values in Focus
}

\author{
Onah Nkechi G. Ph.D \\ Department of Religion and Cultural Studies, University of Nigeria, Nsukka; Email: gloria.onah@unn.edu.ng \\ Ali Alphonsus N. \\ Department of Geography, University of Nigeria, Nsukka; Email: alphonsus.ali@unn.edu.ng
}

\section{Eze Ekenedilichukwu}

Department of Religion and Cultural Studies, University of Nigeria, Nsukka; Email:ekene.eze@unn.edu.ng

\section{Doi:10.5901/mjss.2016.v7n6p299}

\begin{abstract}
Climate change affects various countries in varying degree. Human activities have been observed to be a major contributor to climate change. Consequently, excessive heat, variation in rainfall pattern, rise in sea level, flooding, drought, erosion among others are been experienced in different countries of the world. In Nigeria climate change is obvious and the government has been battling to meet the challenges of mitigating this without much success. The search for more sustainable climate change mitigation strategies becomes necessary. The option of traditional religious practices and values in this regard has not been adequately explored. This is what the study sets out to achieve. Drawing data from literature and in-depth interviews, the study argues that some useful African traditional religious values and practices such as respect for the land divinity, maintenance of sacred groves and forest among others offer good and alternative strategies for climate change mitigation in Nigeria.
\end{abstract}

Keywords: Climate change, environment, mitigation, African traditional religion, Nigeria

\section{Introduction}

Climate change is the greatest environmental challenge the world is battling with today. It is a phenomenon that is affecting various countries across the globe in varying degree. Climate change denotes:

a significant and lasting change in the statistical distribution of weather patterns over periods ranging from decades to millions of years. It may be a change in average weather conditions, or in the distribution of weather around the average conditions (i.e., more or fewer extreme weather events). (IPCC 2007)

In the Intergovernmental Panel on Climate Change (IPCC) usage, climate change means any change in climate overtime, whether due to natural variability or as a result of intense human activities in the environment (Zabbey, 2007). According to IPCC (2001) and USNCDC (2001), the global average surface temperatures have increased by about $0.6 \pm$ $0.2^{\circ} \mathrm{C}$ since the late $19^{\text {th }} \mathrm{Century}$, and 0.2 to $0.3^{\circ} \mathrm{C}$ over the past 25 years. These temperature has been projected to increase by anywhere from 1.4 to 5.80 from 1990 to 2100 (Nwagbara, ljioma, Chima, 2010:526 citing IPCC 2001).

Numerous researchers have noted that the ongoing climate change is strongly associated with human activities (anthropogenic) (IPCC 2001; Cunningham and Cunningham 2004; Gbenda 2010; Akpodiogaga and Odjugo 2010; COMECE, 2011; Idowu et al., 2011). On a global scale, the IPCC confirmed that global anthropogenic greenhouse gas emissions increased by $70 \%$ for the period 1970 to 2004 (COMECE, 2011). Similarly, the IPCC report as noted by (Zabbey 2007:2-3) stated that:

a. The global average surface temperature has increased over the $20^{\text {th }}$ century by about $0.6^{\circ} \mathrm{C}$. Most of the warming occurred in the 20th century, during two periods, 1910 to 1945 and 1976 to 2000.

b. Satellite data showed that there are very likely to have been decreases of about $10 \%$ in the extent of snow cover since the late 1960s, and ground-based observations showed that there is very likely to have been a reduction of about two weeks in the annual duration of lake and river ice cover in the mid and high latitudes of the Northern Hemisphere.

c. There has been a wide spread retreat of mountain glaciers in non-polar regions during the $20^{\text {th }}$ century.

d. Global average sea level has risen and ocean heat content has increased, 
i. Tide gauge data showed that global average sea level rose between 0.1 and 0.2 metres during the $20^{\text {th }}$ century.

ii. Global ocean heat content has increased since the late 1950s.

e. Northern Hemisphere spring and summer sea-ice extent has decreased by about 10 to $15 \%$ since the 1950 s.

Climate change manifestations are never the same in every part of the globe. The on- going manifestation has not been globally uniform (Meyer, 1996 cited in Nwagbara, ljioma, Chima, 2010). For instance, the rising temperature has increased rainfall level in some regions while it has reduced the levels for some other regions, thus making some areas wetter and drier. For the areas that are getting wetter, they may experience among other things flooding as grounds become saturated with water, transporting capacities of rivers and tributaries are exceeded, dams collapse or fail under the pressure of water in excess of their carrying capacities and so on (Nwagbara, Ijioma, Chima, 2010: 527). In Nigeria, for example, it has resulted in drought, erosion and flood disasters which have been affecting most part of the country leading to loss of lives and destruction of properties (Aremu and Olatunde,2012; Agbonkhese et al, 2014). The devastating effect of climate change poses a great challenge to all the machineries put in place by Federal Government for preventing such ecological disaster. In view of this situation, the rational for this study lies on the precept that African traditional religion has some ethical principles and guiding values in relation to our environment. This offers an alternative view towards mitigating climate change in Nigeria. This is not to displace government's effort rather it acts as a contribution to the comprehensive effort needed to redress the situation. The study is meant not only to provide information on this phenomenon but could have broader policy implications for Climate change mitigation in Nigeria.

\section{Methodology}

This article relies on data collected from government documents, journals, books, Newspapers and Key- informant interviews. This approach was geared towards gaining insight into the subject matter. Key- informants were randomly selected and interviewed from purposively selected communities in Abia, Anambra, Delta, Ebonyi, Enugu and Rivers States of Nigeria. This is to identify those African traditional religious values and practices that will complement efforts of the governments in mitigating climate change in Nigeria. The data collected were qualitatively and critically analyzed.

\section{Causes of Climate Change}

The causes of climate change can be divided into two namely natural processes and human activities. According to Akpodiogaga and Odjugo (2010:67) the natural processes (biogeographical) are the astronomical and extraterrestrial factors. The astronomical factors include the changes in the eccentricity of the earth's orbit, changes in the obliquity of the plane of ecliptic and changes in orbital procession while the extraterrestrial factors are solar radiation quantity and quality. Akpodiogaga and Odjugo further notes that the anthropogenic factor in climate change involves human activities that either emit large amount of greenhouse gases into the atmosphere that depletes the ozone layer or activities that reduce the amount of carbons absorbed from the atmosphere. Such human factors that emit large amount of greenhouse gases include industrialization, burning of fossil fuel, gas flaring, urbanization and agriculture. While human activities that reduce the amount of carbon sinks are deforestation, alterations in land use, water pollution and agricultural practices. The emitted greenhouse gases are carbon dioxide $\left(\mathrm{CO}_{2}\right)$, chlorofluorocarbons (CFCs), and sulphuric hexafluoride (SF6) among others. They further observed that although climate change is caused by both natural and anthropogenic factors the later contributes more. Also Cunningham and Cunningham (2004) observed that $\mathrm{CO}_{2}$ is by far the important cause of anthropogenic climate change because burning fossils fuels, making cement, burning forests and grasslands, and other human activities release nearly 30 billion tons of $\mathrm{CO}_{2}$ every year, on average, containing some 8 billion tons of carbon (cited in Ajaero, Akukwe and Asuoha 2010:1). In a similar vein, COMECE (2011:3) said:

Climate does change naturally over time in response to external and internal factors. However of most significance for climate today are the changes occurring in the composition of the atmosphere, Greenhouse gases, such as carbon dioxide, methane and nitrous oxide, exert a disproportionate influence on the temperature of the Earth. Measurements taken from a variety of sources, such as bubbles of air in deep ice cores, show that the concentration of greenhouse gases has increased as a result of human activities to a level higher than at any time in the last 650,000 years.

In their own contribution, EPA United States Environmental Protection Agency (2013) also pointed out that both natural and human factors change Earth's climate; however, most of the observed warming since the mid-20th century is due to human-caused greenhouse gas emissions. Climate change has a cumulative effect on natural resources and 
balance of nature (Igwebuike et al 2010). Climate change has resulted in environmental problems such as extreme heat, flooding, erosion, rising sea levels, Cyclone, tornadoes, hurricanes, landslides, drought and famine with far reaching socio-economic consequences.

\section{Climate Change Manifestations in Nigeria / Impact of Climate Change in Nigeria}

The World Bank estimates that the developing world will suffer about 80 percent of the damage of climate change despite accounting for only around one third of greenhouse gases in the atmosphere (Parayre, 2009). The impact of Climate change on Nigeria is enormous with deleterious effects on livelihood of the citizens. This could be articulated to include the following:

\subsection{Frequent environmental crisis/disaster}

Climate change has led to frequent environmental disaster in the country. In Nigeria, the manifestation of climate change can be seen in persistence drought and desertification in the north and erosion and flooding in the South. Gbenda (2010: 182) notes that Kebbi, Sokoto, Zamfara and Adamawa States are experiencing persistence drought. While Sahara desert is affecting Jigawa, Katsina and Yobe areas. He also observes that there is rising sea level and inundation of coastal lands by sea water in the Southern part of the country. Coastal areas such as Warri, Bonny, Brass, Yenogoa, Degema, Ahoada and Okirika are at risk in the case of persistence rise in Sea level. In Enugu State, three hundred and seventeen critical erosion sites have been identified. Lives have been lost and villages washed away because of erosion. The Federal government has declared Anambra State, a disaster zone (Gbenda cited in Onah and Chinnah 2013). Oyo, Kogi, Benue, Plateau, Adamawa, Delta, Bayelsa, Anambra, Jigawa, Kano, Bauchi, Kaduna, Niger, Nasarawa, Taraba Cross River, Edo, Lagos, Imo States, Kwara, Katsina, Gombe, Ogun, Ondo, Ebonyi, Abia, Rivers States, Sokoto, Kebbi, Zamfara, Yobe, Enugu, Ekiti, Osun, Akwa-lbom, Borno States and the FCT were ravaged by floods in 2012 (TaiwoObalonye 2012:3) in varying degrees. Lives were lost, millions were displaced, farmlands washed away, livestock and property worth millions destroyed. Commenting further on flooding in Nigeria, Aminu (2012) reported the Nigerian Red Cross society as saying that the 2012 flood disaster is the worst in 40 years. In the following year some parts of Plateau, Kebbi and Cross River States were flooded as a result of heavy rainfall leading to loss of lives, damage to properties including livestock and crops (Lawson 2013). In a similar vein, Nigeria loses about 350,000 hectares of land every year to desert encroachment in the northern part of the country. This has led to demographic displacements in villages across 11 states in the North. It is estimated that Nigeria loses about \$5.1billion every year owing to rapid encroachment of drought and desert in most parts of the north (Odiogor 2010). This is a source of threat to the citizens.

\subsection{Low Agricultural production/Food Crisis}

Climate Change has a great effect on agriculture leading to food crisis. Nigeria has a total land area of 983,213 square Kilometers of which 773,783 sq. kilometeres are in the savanna zones 75,707sq. kilometers are in the derived savanna zones and 133,717 square Kilometers are in the forest zone (Omofonmwan and Osa-Edoh 2008:53). Over 70\% of Nigeria's population is engaged in agriculture as their primary occupation and means of livelihood (Idowu et al. 2011: 146). However, drought and flood which are as a result of climate change undermine agricultural production and food availability in the nation. Consequently, food security is threatened. The erratic rainfall leading to flooding in many parts of Nigeria has impacted on the nation's agricultural production. Commenting on this, Obasi (2012) lamented that over 5,000 farmlands were washed away. Farms around the River Niger or linked to its tributaries, suffered greatly. In Kwara State, it was reported that over 3,200 hectares of rice plantation have been washed away. Quoting Delta State commissioner for Agriculture and Natural Resources, Misan Kubeyinje, the hardest-hit were the fish, pig and crop (such as cassava and rice) farmers. Meanwhile, when some regions are experiencing excessive rainfall others are experiencing drought which affects harvest and live stock production. Availability of grasslands for grazing becomes scarce resulting in loss of weight for the animals and reduction in dairy product. The warming trend associated with climate change also affects the production of millet, guinea corn, maize, and rice. It further undermines storage of vegetables and root crops (Igwebuike et al 2010). The reduction in food production is a high threat to food security and this can aggravate the problem of poverty already in existence. 


\subsection{Social dislocation and conflicts}

The challenge of increasing climate change-induced migration has led to conflicts among communities. For example, there are incidences of cattle rearers from the north encroaching on lands in southern part destroying farmlands. The resultant conflicts have led to insecurity of lives and properties as many have met their untimely death in the conflict that erupted. Many have also abandoned their homes and means of livelihood for safety. For instance clashes between Tiv people of Benue State and Fulani herdsmen over grazing land have been reported. In the conflicts that took place in Agatu Local Government area, about 50 persons were reportedly killed while over 10,000 persons became refugees (Abba 2013). Odiogor (2013) reported of similar clashes between Hausa/Fulani cattle men in Delta State where the cattle rearers have attacked communities in Ibusa in Oshimili North, Ogume in Ndokwa West local government areas. In Ogume, no fewer than 10 persons were killed in a clash with the herdsmen over the destruction of their farms.

\subsection{Human Health Hazard}

Climate Change has serious implication for human health. High temperature, drought and changes in rainfall pattern affect fresh water supply and predispose people to infection and other health challenges. Change in climate condition increases the vulnerability of individuals to diseases and mortality. In many parts of the country floods are increasing in frequency and intensity as aforementioned. WHO (2013) confirms that floods contaminate freshwater supplies, heighten the risk of water-borne diseases, and create breeding grounds for disease-carrying insects such as mosquitoes. They also cause drowning and physical injuries, damage homes and disrupt the supply of medical and health services. Drought also leads to water scarcity and significant decrease in fresh water. This can compromise hygiene and increase the risk of diarrhea and other water-borne diseases such as typhoid fever, cholera and river blindness.

\section{Governments Policies on Climate Change}

Nigeria has always been interested in and supportive of global actions against climate change and proffering solutions to noticeable impacts. The country is a signatory and accedes to most international conventions and protocols such as UNFCC convention and Kyoto Protocol (on GHG and climate change); Vienna convention and Montreal Protocol (on stratospheric Ozone Depletion) and Stockholm convention (on POPs). Nigeria is a signatory to Agenda 21 in Rio, is on a number of clean Development Mechanism (CDM) projects and is elected into executive board of the mechanism (Federal Ministry of Environment Special Climate Change Unit (2011)

The existing polices, programmes, actions and measures are insufficient to address the level of challenges posed by climate change in Nigeria. It is against this back drop that governments have developed National climate change polices and response strategies that sets out the directions of the stake shareholders on climate change. The policies by the Federal and State governments provide an integrated, harmonized and mulit-sectoral, mitigation and other measures collectively referred to as "cross-cutting measures".

The primary priority areas of government's policies on climate change are climate change adaptation and mitigation. Climate change adaptation is the adjustment in natural or human systems in response to actual or expected climatic stimuli or their effects, which moderates harm or exploits beneficial opportunities. Such adjustment may be preventive or reactive, private or public, autonomous or planned (Intergovernmental Panel of Experts on climate change (IPCC) (2007). Climate change mitigation is a secondary priority of the policy on climate change. Mitigation means the human interventions to reduce the sources of climate change or enhance sinks of green-house gases.

In a nutshell, the government policies on climate in Nigeria aimed at promoting adaptation and mitigation measures in the vulnerable socio-economic sectors (NSPA-CCN, 2011; Lagos State Climate Change Policy, 2012-2014) include the following:

1. Protection of water resources from pollution through necessary legal and institutional instruments and implementation programmes to sustainably extend and improve water supply and water management infrastructure.

2. Promotion of the adaption of improved agricultural system for both crops and livestock by diversifying livestock and improved range management, increase access to drought resistant crops, livestock feeds, adapt better soil management practices, provide early warning/meteorological forecasts, increase planting of native vegetation cover, promotion of re-greening efforts and intensification of crops and livestock production in place of slash and burn.

3. In land use, forestry and Biodiversity, governments shall promote a aforestation and re-aforestation 
programmes particularly with fast maturing tree species and conservation of remaining forested area; promotion of alternative energy sources in order to reduce dependency on biomass for energy needs in both urban and rural areas; strengthening the enforcement of laws and good governance of forest and other natural resources; implementation of legislative and control measures such as fencing to limit access to protected forests and designation of more protected zones to protect endangered species.

4. Facilitating the availability of health facilities, equipment and medicine to assist in early diagnosis and treatment in climate change related disease; promotion of awareness among populations on climate change related diseases and prevention. Governments shall also expand water and sanitation (NATSAN) infrastructure particularly in informal settlements to reduce outbreaks and spread of water borne diseases and provide access to health care services to vulnerable groups such as pregnant women, children, older persons and others.

5. In human settlement and housing, governments shall assist communities to reduce vulnerability through participatory planning of land use and housing, discourage housing settlement practices that are maladaptive in the face of climate change; discourage building/urban encroachment into vulnerable areas, high risk zones and low-lying areas and the strengthening of rural settlements in order to reduce migration.

6. To reduce greenhouse gases (GHGs) emissions from the transport sector; governments shall invest in alternative modes of transport such as rapid bus transit (RBT), rail system, air and water transport to reduce road traffic and associated carbon-dioxide emissions; encourage non-motorized modes of transport such as bikeways and pedestrian walk ways in urban centers; and encourage the importation of fuel-efficient transportation means such as plug-in hubris, eclectic trains (ie, city trams).

7. In manufacturing and energy industries, governments shall support the development of low-cost green initiatives and technologies, promote sustainable waste management practices such as recycling and re-use including waste-energy opportunities that can among other benefits, attract carbon finance to reduce GHG emissions and other forms of environmental pollution in production processes and product delivery. Governments shall also promote energy sources the main source of its energy through increasingly investing in alternative energy research and development $(R \& D)$, technology development, acquisition, transfer and adoption.

8. Cross-cutting measures: Implementation of the above adaptation and mitigation polices recommendations will not be effective without a set of critical pillars that cut across both adaptation and mitigation and across all sectors of national development. These pillars are called "enablers" and include

(a) Education training and public awareness to raise the level of awareness of climate change among the general populace and to impart specialized climate change knowledge and skills to enable the country or the nation address climate change risks as well as take advantage of its opportunities.

(b) Information and knowledge management systems to enhance the capacity of climate change information and knowledge management systems for improved response to climate change.

(c) Technology development, transfer and adoption to enhance the flow of know-how, experience and equipment for mitigating and adopting to climate change amongst different stakeholders such as governments, private sector entities, financial institutions non-governmental organizations and research education institutions (IPCC, 2000).

(d) Gender Dimension: In recognition of the differentiated impacts of climate change on woman, men, youth, the physically challenged and the poor as well as their differentiated roles, abilities and responsibilities in responding to climate change, the assessing vulnerability, impacts and risks of climate change and governments shall promote involvement of women, youth and physically challenged in climate change monitoring and decision making processes.

Despite these laudable efforts by the government, mitigating climate change still proves problematic.

\section{African Traditional Religious Values as Response to Climate Change Mitigation}

In the traditional Africa a variety of techniques were used to protect the environment and mitigate climate change. As Ugwuanyi (2011:108) rightly observed, environmental ethics based on African worldview provides a viable alternative to address the environmental challenges of modernity. African traditional religion is the indigenous religion of the Africans. The African world-view is profoundly religious. They take their religion seriously in any activity because of their strong belief in the intricate interactions of this world with the invisible world of reality. At the heart of this two interacting worlds of traditional Africans is man who is required to maintain unalloyed ontological, ethical balance with all realities of these 
world for his own welfare and that of others (Mbiti, 1969 and Ekwunife 2004).

African traditional religion is very close to nature and has created eco-friendly structures, practices and sanctions that were of enormous benefit in protecting the environment. Africans idea and position in the world have been of immense help to them in dealing with their environment chivalrously. Man, in Africa, believes that he is at the centre of the world and is surrounded by spirits, powers and forces greater than him. In order to live harmoniously not only in his relationship with the Supreme beings but also in his environment, Africans fashioned beliefs, practices and taboos couched in religious tapestry. He believes that his actions could make or mar his existence since man's actions are judged by the Supreme Being. For the Africans the universe created by God is made up of two interacting worlds, namely the physical world or visible world and the spiritual world or invisible world. The physical world comprises the earth populated by human beings, animals, birds, reptiles, and other animate and inanimate things such as land, rivers, forests, mountains, valleys, grasses, seas, lakes among others. While the spiritual world or invisible world is made up of ontological beings such as the Supreme Being, the divinities, deities, spirits and ancestors (Mbiti 1969; Awolalu and Dopamu 1979; Metu 1987; Ekwunife 1990; Gbenda 2006).

In view of this, African beliefs and practices make them to place value on their environment since God cannot be removed from it. The understanding is that everything that belongs to the ecosystem and the environment is profoundly religious and many things on earth are held in high esteem for religious reasons, especially when they are thought to be dwelling places for the spirits (Gbenda 2010). In Africa therefore, respect for the environment is believed to be divinely ordered, for man in Africa cannot survive without the divine and the divine cannot be disassociated from His creatures. Man is supposed to live in harmony with things in his environment because environment is part of his life. Hence, there are immutable laws, customs and sanctions to guide human actions in relation to the environment. Such conservative and preservative mechanism could be harnessed in mitigating climate change and protecting the environment. For instance, in many African communities land is deified and is referred to as mother earth and preserved. Land-divinity is prominent among the arch-divinities. Among the Igbo people of Nigeria, for example, (Ala/Ani/Ana) the earth goddess is the most important divinity and it is regarded as the goddess of fertility and guardian of morality in conjunction with the ancestors (Arinze 1970; Iwe 1979; Ilogu 1985; Ifesieh 1989; Ike and Edozien 2001; Ugwu and Ugwueye 2004). Reflecting further on this llogu (1985:35) notes that "many social offences become aru or pollution or abominations because they infringe on the laws of the earth goddess". Such actions as incest, stealing of yam, homicide, adultery etc were avoided by the people since they are directly against the earth goddess. When the earth is desecrated by men, they suffer it. The earth goddess inflicts the people, leading to disastrous consequences such as drought and famine. This is because it is believed that the action of an individual could affect other members of the community. This point was underscored by Mbiti (1969) who noted the importance of community/communualism among traditional Africans "I am because we are, and since we are, therefore I am". In order to ensure that such do not happen, sanctions and prohibition of the mother earth is strictly adhered to and if violated, is appeased by stipulated propitiatory and expiatory sacrifices.

More so, taboos and sanctions were instituted to ensure ecological preservation and reservation. According to Gyampoh et al (2009) in order to provide means of protecting the water bodies, some days are set aside when people are forbidden from going to the river or stream for any purpose. Africans belief that spirits live in water bodies also. Sources of water such as spring, streams and rivers are linked with a deity. Taboos which regulate the activities of people in these sources of water were given. For instance, people are not allowed to bath or wash clothing there, aquatic animals living in some of the rivers or streams were not killed and some days were set aside when no person was allowed to engage in any activity in and around the stream or river. Taking Neke-Uno Nike community in Enugu State as an example, people are not allowed to fish in Enekereje and Ishiyiagu streams (Samuel Okoh, interview, 10/1/2014). The same is applicable in Umuobiala community in Isikwuato Abia State were in Une stream fishes and crocodildes are not killed (Tochi onwukwe, interview 5/2/ 2014). Stories of people who suffered degrees of calamity for violating the sanctions and taboos have always been told which deterred others from violating them. This bestows a sense of responsibility on individuals to conserve aquatic life and ensure sustained biodiversity.

Various totemic animals exit in various forms in African society. An animal is considered to be totemic depending on the society. These totems are believed to have link with the ancestral world. Quacoopome (1987) posits that totemic animals are found mainly among wild animals with special qualities such as python, tortoise, monkey, crocodile, leopard etc. Even though animal constitutes food for man, these totemic animals are not meant to be killed for any purpose; not even for sacrifice (domestic animals are meant for food and sacrifice). If one accidentally kills a totem, it is buried and the funeral rites performed as that of a human being. For instance in Mgbidi and Idemili clans of Imo (Wisdom-Bassey, 2014:12) and Anambra states respectively, pythons are not killed because they are sacred ( Chidi Okonkwo, interview, 23/1/ 2014). In Awka Anambra state monkeys are revered (Chidi Okonkwo, interview, 23/1/2014). In Achi Enugu State, tortoise, are sacred (Precious Ukeachusim, interview, 18/2/2014). For Ibusa people of Delta State and Nnewi people of 
Anambra state, Rabbit is a totemic animal (Nnamdi Anilefo 31/1/ 2014) while green snake is revered in Okposi, Ebonyi State ( Samuel Omeranu, 31/1/2014) and Umuobiala community in Isuikwuato Abia State ( Tochi onwukwe, interview $5 / 2 / 2014)$. The death of a totem in an African society was mourned. This has helped in protecting and preventing such species of animals from going into extinction.

In Africa, sacred forests or groves have special place and significance. These groves housed the shrines of deities and are reverenced. Farming and hunting are usually prohibited in such areas. Among the Igbo people for example, sacred groves are the earthly abode of the guarding spirits. Some of these groves were owned by deities and the people carry out their traditional religious activities on them (Emeasoba and Ogbuefi, 2013). Taking Umuaturu in Etche Local Government Area of Rivers State as an example, Okahia Egbede is a sacred groove where all the religious activities of the Egbede deity are been carried out. No one is allowed to go into the forest except the priest of Egbede. Okahia Egbede is so sacred that every newly appointed priest of Egbede must vacate his family compound to live in that forest. If any priest fails to live within that vicinity, that priest is bound to die within a short time. Every animal sacrificed to Egbede deity are owned by the priest of Egbede, no one is allowed to hit or kill the animals. If anyone kills any of the animals belonging to Egbede, that person will receive the wrath (anger) of Egbede (Lucky Ngozi interview 18/2/ 2014).

Some forests were designated evil forests because they received all manners of objects or items; including the corpses of those who died accursed death. The evil forests may not be evil but were designated so, to frighten people from violating it. These sacred groves or forests provided natural habitat to the totemic animals. The sacred groves also helped in preserving both flora and fauna and other ecological values.

It is also believed that sprits have their abode on natural objects such as trees. According to Parrinder (1962:52), "all trees are thought to have souls of their own, and some are regarded as the dwelling places of other powerful spirits which take up temporary abode there". Before such trees are cut down some prescribed rituals are performed to appease the spirits that inhabit them. In Igbo land for an example, some trees are tied to fecundity. Hence, Ogbu Chi (tree of life), Ogilisi (Spiritual tree) and Udalla tree play significant symbolic roles in family life (Ezeanya 2011:16) and therefore are revered. It is believed that the spirits of the ancestors and amicable deities inhabit the Ogilisi and its use in cultural activities such as landmark is with the sure belief that the spirits are involved ((Ezeanya, 2011). In so doing, deforestation, a contributory factor to climate change is avoided while green forestry and wildlife are preserved.

\section{Recommendation and Conclusion}

Climate change is a devastating phenomenon affecting the world today. From all indications climate change poses a real threat to humanity. This article has shown that climate change is a pervasive issue in Nigeria affecting food production, human health and generating communal clashes. Climate change, caused by both natural and anthropogenic factors, with the later as the main causative agent needs mitigation to reduce vulnerability of our environment. The anthropogenic factor in climate change entails human activities that either increases the amount of greenhouse gases in the atmosphere that depletes the ozone layer or activities that reduce the amount of carbons absorbed from the atmosphere. In order to to address the challenges posed by climate change, the Nigerian government has developed National climate change polices and response strategies. But this has not yielded the expected result as industrialization, deforestation among others leading to variation in temperature, flooding, erosion and drought are witnessed in different parts of the country. It becomes imperative to bring to limelight the traditional religious practices such as respect for the land divinity, maintenance of sacred groves and forest among others as alternative tools in mitigating climate change in Nigeria. We therefore, recommend a comprehensive reconsideration by policy makers in Nigeria and the rest of the world toward climate change in which indigenous religious practices are brought into the mainstream of policy guidelines to address climate change issues. This will add to the comprehensive effort needed to save the climate.

\section{References}

Abba T. (2013). Nigeria: Fulani/Farmers Clashes Claim 300 Lives in Five Months. Daily Trust May 26 accessed on 7/2/2014 from http://allafrica.com/stories/201305271689.html

Agbonkhese ,O, A., Aka, E. G., Joe-Abaya, E. O., Ocholi, J., and Adekunle, M. A. (2014) Flood Menace in Nigeria: Impacts, Remedial and Management Strategies. Civil and Environmental Research, Vol., 6, No. \$, pp. 32-40

Ajaero, C, K, Akukwe, T.I. , Asuoha, G.C. (2010) Climate Change: Concepts and issues in R.N.C. Anyadike, I.A. Madu and C.K. Ajaero (eds) Climate Change and the Nigerian Environment. Conference Proceedings of Department of Geography University of Nigeria, Nsukka.

Akpodiogaga P. and Odjugo O. (2010) Global and regional analysis of the causes and rate of Climate in R.N.C. Anyadike, I.A. Madu and C.K. Ajaero (eds) Climate Change and the Nigerian Environment. Conference Proceedings of Department of Geography 
University of Nigeria, Nsukka.

Aminu, A. (2013). 2012 Flood Disaster Worst in 40 years. Accessed on October 21, 2013 from http://www.dailytimes.com.ng/ article/2012-flood-disaster-worst-40-years-red-cross

Aremu, J. K. And Olatunde, A. F. (2012) Drought Intensities in Sudano- Sahelian Region of Nigeria. Journal of Sustainable Society, Vol. 1, No. 4. Pp.88- 95

Arinze, F. A. (1970) Sacrifices in Ibo Religion. Ibadan: Ibadan University Press.

Awolalu,. Omosade J. and Dopamu, .Adelumo P. (1979) West African Traditional Religion. Benin: Onibonoje Press and Book Industries Ltd.

COMECE (2011) A Christian View on Climate Change. The Implications of Climate Change for Lifestyles and EU Policies. Belgium: Commission of the Bishops' Conference of European Community. Accessed on 17/5/2015 from http://www.gci.org.uk/ Documents/COMECE_pdf

Cunningham, W., P and Cunningham, M., A (2004): Principles of Environmental Science: Inquiryand Applications (2nd Ed.), New York: McGraw- Hill.

Ekwunife, A.N.O (2004) Values in traditional and Moder4n Nigerian Society: A Study in Leadership in M. I. Okwueze (ed) Religion and Societal Development. Lagos: Merit International Publications.

-(1990) Consecration in Igbo Traditional Religion. Enugu: SNAAP PRESS LTD.

Emeasoba R.. and Ogbuefi J.,U. (2013) The Dynamics of Land Ownership by Deities in Anambra State Nigeria. Research on Humanities and Social Sciences.3 (7), 61-67.

Ezeanya, O.,C.(2014) Traditional Igbo marriage symbols: A call for Teleological family Orientation Nsukka Journal of Religion and Cultural Studies. 4(1), 15-32.

Federal Ministry of Environment Special Climate Change Unit. (2011) National Adaptation Strategy and Plan of Action on Climate Change for Nigeria (NASPA-CCN). Building Nigeria's Response to Climate change (BNRCC)

Gbenda, J .S. (2006) African Religion and Christianity in a changing world: A comparative approach. Nsukka: Chuka Educational Publishers. -(2010) Religion and Ecology: A comparative Study. Makurdi: Obeta Printing and Publishing co.

Gyampoh, B. A., Amisah, S., Idinoba, M.,\& Nkem, J. (2009). Using Traditional Knowledge to Cope With Climate Change in rural Ghana. Accessed on 17 March, 2014 from www.fao.org/docrep/011/i0670e14.htm.

Idowu, A.. .A, Ayoola S., O, Opele A.I and Ikenweiwe, B. N. (2011) Impact of Climate Change in Nigeria: Iranica Journal of Energy \& Environment 2 (2): 145-152.

Ifesieh E. I. (1989) Religion at the Grassroots (Studies in Igbo Religion). Enugu: Fourth Dimension Publishing Co.

Igwebuike M. N., Odoh F. C., Ezeugwu C.I. Oparaku N.F., Oparaku O.U. (2010) Causes of Climate Change in R.N.C. Anyadike, I.A. Madu and C.K. Ajaero (eds) Climate Change and the Nigerian Environment. Conference Proceedings of Department of Geography University of Nigeria, Nsukka.

Ike O. F. and Edozien N. N. (2001) Understanding Africa, Traditional Legal Reasoning Jurisprudence and Justice in Igbo land as a basis for culturally rooted and sustainable Development. Enugu: CIDJAP Publications.

Ilogu E. (1974) Christianity and lgbo Culture. Onitsha: University Publishing Company.

IPCC(Intergovernmental panel on climate change) (2000): Methodological and Technological Issues in Technology Transfer: A special Report of the Working Group III of the IPCC Summary for Policy makers htt://www.ipcc.ch/pdf/special-reports/spm/srtt-en.pdf

IPCC (2001), "Climate Change 2001: Impacts, Adaptation and Vulnerability", Working Group II Contribution to the Third Assessment Report of the Intergovernmental Panel on Climate Change, "Chapter 18: Adaptation to Climate Change in the Context of Sustainable Development and Equity", Cambridge University Press, Cambridge.

IPCC(Intergovernmental panel on climate change)(2007): Synthesis Report Summary for Policy makers. Contributions of working Group II to the fourth Assessment Report of the intergovernmental Panel on climate change. Cambridge University Press, Cambridge UK accessed at htt://www.ipc.ch/pdf/assessment-report/ar4/wg2/ar4-wg2-spm.pdf.

Iwe N. S.S. (1979) Christianity in Igbo Culture in Africa. Onitsha: University Publishing Company.

Lagos State Government (2012): Climate Change Policy 2012-2014. Lagos State Ministry of Environment First Draft.

Lawson M. (2013) Floods in Nigeria. Accessed on October 22, 2013 from http://floodlist.com/africa/floods-nigeria-september-2013

Mbiti, J. S. (1969). African Religions and Philosophy. London: Heinemann Ltd.

Metuh I. E. (1987). Comparative Studies of African Traditional Religion. Onitsha: Imico Publishers.

Ngozi L. (2014) Personal Communication.

Nwagbara, M. O. ljioma M.A. Chima G. N. (2010) Climate Change and flooding in Northern Nigeria: An examination of rainfall Trends over the region in R.N.C. Anyadike, I.A. Madu and C.K. Ajaero (eds) Climate Change and the Nigerian Environment. Conference Proceedings of Department of Geography University of Nigeria, Nsukka.

Obasi T. (2012) Flood crisis: Implications for agric and food security in Nigeria.Accessed from http://www.bussinessdayonlin.com.

Odiogor H. (2010) Special Report on Desertification in Nigeria: The Sun eats our Land. Accessed on October, 22 2013.from http://www.vanguardngr.com/2010/05/special-report-on-desertification-in-nigeria-the-sun-eats-our-land/

Okoh S. N. (2014). Personal Communication.

Okonkwo C. (2014). Personal Communication.

Omeranu N. S. (2014). Personal Communication

Onwukwe, T. (2014) Personal Communication 
Onah N. G. and Chinnah U. K. (2013) The Role of Christianity in Environmental protection in Nigeria. Journal of the Nigerian Association for the Study of Religions. 23. (2), 369-382.

Omofonmwan, S.I. and Osa-Edoh G.I. (2008) The Challenges of Environmental Problems in Nigeria. J. Hum. Ecol., 23(1): 53-57.

Parayre C. (2009) Africa wants polluters to pay for climate change. Accessed on October 17, 2013 from http:www.google.com/hosted news/afp/article/ALeqM5gsg29g

Parrinder, E.G. (1962), African Traditional Religion. London: Sheldon press.

Quarcoopome, T. N. O. (1987). West African Traditional Religion. Ibadan: African Universities Press.

Taiwo-Obalonye, J. (2012) Jonathan approves \#17.6bn for flood victims. Daily Sun Wednesday, Vol.7, No. 2470 p. 3.

Ugwu C.O.T and Ugwueye L. E. (2004) African Traditional Religion: A Prolegomenon. Lagos:Merit International Publications

Ugwuanyi L. O. (2011) Advancing Environmental Ethics Through the African World-View. Mediterranean Journal of Social Sciences Vol. 2 (4) $107-114$

Ukeachusim, Precious. (2014) Personal Communication

United States Environmental Protection Agency (2013) Causes of Climate Change. Accessed on October 9, 2013 from http://www.epa.gov/climatechange/science/causes.htm/ last updated Monday, September 092013

Wisdom-Bassey, V. (2014) Our god is python. Nigerian Community where indigenes worship snake. Saturday Sun, February 1, Vol.11. No. 578 p.12.

Zabbey N. (2007) Climate Change and Flooding: Fate of Riverine Communities in the Niger Delta Paper delivered at an interactive roundtable organised by Stakeholder Democracy Network (SDN) in commemoration of World Environment Day, SDN Conference Room, Port Harcourt, Nigeria, $5^{\text {th }}$ June. 
ISSN 2039-2117 (online)

ISSN 2039-9340 (print)
Mediterranean Journal of Social Sciences MCSER Publishing, Rome-Italy
Vol 7 No 6 November 2016 